\title{
A History of Internships at CBC Television News
}

\author{
Marlene Murphy ${ }^{1}$ \\ Senior Writer, Canadian Broadcasting Corporation, Toronto, Canada, \\ marlenetheresamurphy@gmail.com
}

\begin{abstract}
Internships are a common component of journalism education in Canada and, in some cases, a requirement for graduation. I look at the history and development of internships, both paid and unpaid, in the English-language national television newsroom of the Canadian Broadcasting Corporation ( $\mathrm{CBC}$ ), Canada's public broadcaster. This account is informed by interviews with CBC staff, union officials, and former $\mathrm{CBC}$ interns as well as a survey of post-secondary education institutions that place interns with the CBC. I explore the establishment of unpaid internships at the CBC and the role of the Canadian Media Guild in creating the contract language defining the parameters of internship placements. Internships at the CBC are perceived by some of the Corporation's staff as a responsibility of the public broadcaster, and representatives of the colleges and universities that participate in the program view the internships as valuable. I argue that the absence of institutional statistics on internships is a missed opportunity to deepen understanding of the role of internships at the CBC, and that systematic information-gathering by academic institutions regarding placements and offers of paid employment would be a useful resource in the debate over unpaid internships.
\end{abstract}

Keywords: internships, television, Canadian Broadcasting Corporation, Canadian Media Guild, unions

The Canadian Broadcasting Corporation $(\mathrm{CBC})$ has a significant role in disseminating news and current affairs programming to Canadians. The roots of the $\mathrm{CBC}$ were established in the 1930s with radio broadcasts, and the public broadcaster's first television stations went on the air in 1952. A Crown corporation, the CBC is one of Canada's largest cultural institutions, with total spending in $2013-2014$ of $\$ 1.87$ billion, with $\$ 975.6$ million of that provided by the federal government (CBC 2015a). The CBC's financial struggles have been widely covered in recent years. In 2012, the government announced a 10 percent cut to the CBC's funding over a three-year period, a move that reduced the government allocation by $\$ 115$ million (CBC 2012). Funding cuts and revenue shortfalls have led to staff reductions, with the CBC president noting in 2014 that he had announced three rounds of major cutbacks since taking the position in 2008, affecting the equivalent of more than 2,100 positions (CBC 2014a). As of April 2014, the CBC had the equivalent of 8,203 fulltime positions (CBC 2015b). The same month, the Corporation announced a plan that will leave the broadcaster with between 1,000 and 1,500 fewer jobs by 2020 (Wong 2014).

The CBC's mandate under the 1991 Broadcasting Act is to provide programming that informs, enlightens, and entertains as well as reflects Canada and its regions (Government of Canada 2014). The Corporation has at least one station in every province and territory in Canada, many of them in the same communities where schools offering journalism programs are located. This prominence, and the CBC's long history of news and current affairs programming, fuelled requests for internships from colleges and universities, and led to the creation of unpaid intern programs in the English and French-language national newsrooms.

This article explores the history of internships in the CBC's English-language national television newsroom, from their introduction in the 1970s with a few paid participants, to the extensive media network that exists today, which offers unpaid placements to dozens of students each year, to a paid program for a small group of students who are completing their final year of study. I address how the Corporation handled the creation and oversight of in-

\footnotetext{
${ }^{1}$ The $\mathrm{CBC}$ was aware that this research was being undertaken by an employee, but the research and publication of this article are independent of the CBC.
} 
ternship programs. I show that staff view offering internships as one of the responsibilities of a public broadcaster, and schools view the internships as a valuable resource. In conclusion, $\mathrm{I}$ argue that more systematic information gathering and information sharing by academic institutions about the CBC internships would contribute to the larger discussion surrounding internships and their efficacy.

The CBC's size and reach mean that internships, both editorial and technical, can be found in various divisions of the Corporation in cities across Canada and beyond. The goal of this research is to establish a timeline for the development of internships at national television news in Toronto, which has not been documented in a comprehensive way by the CBC. The scope of the research is limited primarily to placements handled by an office in Toronto that accepts applications from across the country for editorial internships. While the first internships in television news are exclusive to that medium, unpaid internships now offered to students from eligible academic institutions, which include television news components, may have radio news or online news components as well.

This research is based on a mixed methods approach. Interviews were conducted with six individuals who have at one time been tasked with responsibilities for the intern program that includes English television news, as well as one manager responsible for the Frenchlanguage program based in Montreal. A senior union representative with the Canadian Media Guild was interviewed on the contract language for unpaid interns. I exchanged written communication with four former executive producers in the newsroom, who provided information about the early years of the program. Four former interns from the 1970s and 1980s offered their written recollections and responses to questions, as well as six former interns whose placements were as recent as 2013. I interviewed six news producers who have been tasked with overseeing interns. In addition, I sent a survey to colleges and universities with journalism programs who participate in the $\mathrm{CBC}$ internship program, generating responses from 10 schools in five provinces. ${ }^{2}$

\section{The Early Years}

The first $\mathrm{CBC}$ initiative identified as an intern program and overseen by national television news was established in 1974. Two senior editorial staff travelled to the University of Western Ontario, Ryerson, and Carleton, the only Ontario schools offering programs in journalism studies at the time (Ryerson School of Journalism 2015). After completing interviews, eight individuals were chosen for a four-month paid summer program. Initial training was provided in Toronto, and the participants were sent to work in local CBC television newsrooms. Vancouver, Regina, Halifax, Ottawa, and Montreal are among the stations where interns were placed that first summer, with a deliberate attempt to not send interns to cities where they had lived or studied. All of the interns were integrated into the reporting staff of the newsroom for approximately 14 weeks before returning to Toronto for the final week of the internship.

One of the interns from the program's first year describes the experience as an extended job interview, suggesting that one of the goals of the program was to identify promising journalists and hire them before the competition did. The internship was regarded as a chance for the Corporation to explore and assess an individual intern's strengths and weaknesses, and a chance for the intern to get four months of full-time paid work. About half of the first group of interns stayed on in the cities where they interned, and there were similar examples in subsequent years. Internships provided local stations across the country with promising talent who had already attracted interest at the national level of the CBC.

An intern from the 1980s observed of the executives who selected him that "it was as if they were trying to shape the future national newsroom by using this training program as a conduit." He believes the intern choices were seen as "a way to bring in new blood, to train print journalists, maybe even a tool for affirmative action." Another remembers the senior editors who interviewed him as being "intense and challenging," even reporting having an

\footnotetext{
${ }^{2}$ In order to ensure frank assessments, participants were advised that while their roles would be identified, their names or those of their post-secondary institutions would be anonymized. All unattributed quotations in the article are drawn from the interviews or the survey.
} 
argument with one of them. A third former intern describes training in which "we had our thinking pushed on the conventions of TV news." Although in some years the program was put on hiatus for financial reasons, the paid summer intern program continued until 1990, with many of the interns who stayed at the CBC moving into senior level reporting and editorial positions.

While the paid summer intern program was established and well known, there are no documented examples of unpaid interns in the television newsroom in the 1970s and 1980s. Former staff during that period suggest the absence of unpaid internships was a result of strong opposition to the idea from unions. Asked about interns in Toronto, one former staff member said, "We did not use that word in the newsroom. Unpaid work would have caused a union action, I am sure." Entry-level work in the television newsroom for recent graduates of journalism programs was often as copy clerks and editorial assistants, who were generally hired on a casual or contract basis.

Developments between 1985 and 1999 saw significant changes at CBC News. In television news, these changes included the addition of a ten-minute newscast broadcast live in five different time zones for a noon-hour current affairs and lifestyle show called Midday, which began airing nationally in 1985. The establishment of CBC Newsworld in 1989 created a 24-hour cable news channel broadcast across Canada. Newsworld International, a specialty channel offered outside Canada, began broadcasting in 1994, and CBC's website, cbc.ca, launched a year later. The development of digital news platforms and newsgathering also led to reorganization and greater integration between radio and television news (Canadian Media Guild 2014).

There does not appear to be a single factor that leads to the establishment of unpaid internships in the national TV newsroom. By the late 1990s, the additional news channels had increased the number of newsroom positions in Toronto from a decade earlier. There were also more post-secondary institutions offering journalism programs. A number of current or former CBC employees had been hired as instructors and professors at various journalism programs, and that appears to be at least partly responsible for an increase in the demand for placements. Several individuals who were at the CBC during this period described receiving calls from past or current $\mathrm{CBC}$ colleagues who were teaching journalism, asking if an internship could be arranged for students. They also confirm that individuals, including students, would regularly approach $\mathrm{CBC}$ News on their own initiative in an effort to arrange an internship. One CBC manager said, "there wasn't a day someone didn't get a call," referring to inquiries about internships and the pressure from schools to offer them.

There was also interest within the CBC in creating opportunities for students to get exposure to the working environment at the Corporation. One individual involved in the development of unpaid internships describes approaching a manager to suggest that "we should be taking in interns from the schools, because that's part of who we are as a public broadcaster. We have great people here who would be really good mentors-we just need a proper system." This sentiment is echoed by virtually every CBC staff member I interviewed: the public broadcaster has a duty to offer learning opportunities. "A public broadcaster must encourage Canadian journalism students to get involved and give them opportunities," one producer told me.

There was one unique initiative in 1999 to broaden the pool of individuals working at the CBC by offering a 12-month paid internship. Open to any applicant, and widely advertised nationwide, it gave participants the opportunity to receive several weeks of training in Toronto before being sent to work in another city in a local newsroom. The ten participants, some of whom had journalism backgrounds, then returned to Toronto and were given placements at programs produced for national distribution. There were designated mentors for the participants, and a requirement to write regular updates on their experiences. There was no guarantee of work at the end of the 12-month period, although several remained with the Corporation. The initiative was discontinued after one year for budgetary reasons.

While there may have been a few informal arrangements in television news, there is no evidence of an established framework for unpaid internships during the 1990s. One CBC employee reports what happened when three university students were offered paid employ- 
ment for the summer by radio news in the 1990s to fulfill internship requirements, describing "some very disgruntled people in the newsroom, saying 'you're bringing in these students and you're getting them to do work and they're taking work away from [...] casual people,' and so we decided not to go that route again."

Individuals who participated in the creation of what is now the unpaid internship program in Toronto acknowledge that discussions about internships based in the national newsroom included questions about accessibility. One describes the number of schools the CBC worked with initially as quite small, and mostly in the Toronto area, saying, "We couldn't offer a salary or a place to stay or a bus ticket," but points out that queries about participation came from universities in other provinces, and explains students across the country are eligible to participate as long as they understand there is no money for a salary or accommodation. Another says of the program, "Yes, it is unpaid. But it is valuable, practical experience, it allows them to network, to test their own abilities, and gauge where they are. As a public broadcaster, I don't have a problem with an internship as long as it's not exploitive, and I don't think it is."

\section{Union Involvement}

Much of the opposition to unpaid internship programs came from the unions representing employees in news programming and involved concerns that internships would be used to respond to staffing shortages rather than to provide mentoring. The 1990s saw a significant organizational change involving unions representing $\mathrm{CBC}$ employees. The establishment of the Canadian Media Guild (CMG) in 1993 came about as part of an initiative to decrease the number of unions at the CBC. The newly named union saw an increase in membership from 700 to 3,000. A merger with the Canadian Broadcast Employees Union in 1998 added another 700 members to the CMG. And, in 2003, the union grew again by about 1,500 members after it won a representation vote against the Communications, Energy, and Paperworkers Union (Canadian Media Guild 2014). The same period also saw labour disputes, with union concerns about the loss of full-time staff positions to contract ones (Mosco and McKercher 2006).

An official with the CMG describes discussions within the union about the contract talks that led to the 1998 collective agreement, saying, "One of the areas people came to be concerned about was the use of interns because they were concerned about interns coming in and actually doing work and not really feeling it was a mentoring program, but it was departments making up for the lack of budget." The union official recalls a debate about an intern policy among elected union representatives and some of those same people would have been on the bargaining committee when contract discussions were underway. He suggests both sides believed in having interns, saying it was "good for the Corporation, good for the union, for the members. The interns usually end up being future members." The union official describes the union position as a quid pro quo, because training for interns acknowledges the obligation to provide training for staff as well. He points to language in a CMG policy that the national executive adopted in 1998, which states that "the interns must be used in such a way as to respect our collective agreements [...] and to enhance the training opportunities given to members of the bargaining unit" (Canadian Media Guild 1998). The policy also affirms "the Guild's first goal is to ensure that resources designated for our members are not being used to train outside individuals. When an employer proposes bringing in an intern, we must be satisfied that employees are given a chance to enhance their own skills" (ibid.).

A manager during this period agrees the union's objections to unpaid interns derive from concerns that the CBC would use interns and casual employees to replace full-time positions. He points to changes in union leadership during the period in the late 1990s, when language on unpaid interns is discussed, and suggests there is an understanding on both sides of the value of putting an internship program in place, as some interns would become future employees. He recalls a conversation with a union executive to craft the terms of the language regarding interns, with the goal of protecting jobs and not opening the door to unpaid labour. 
The union and $\mathrm{CBC}$ management approved the first contract language on unpaid internships in 1998. Key provisions are that the interns do not fill vacancies or replace existing staff, that the internship is for training purposes and to augment learning at a recognized educational institution, that interns are assigned a mentor, and that interns not be paid for their work, in recognition of the fact that they are part of a post-secondary education program and not newsroom employees who could be assigned to fill vacancies or handle duties without supervision (CBC-CMG 2014, 110-111).

The 1998 collective agreement signals a different emphasis from the first paid intern program of the 1970 s and 1980s. The early programs are regarded by the CBC as a way for managers to identify and evaluate potential employees. Managers responsible for the intern program all point to the new contract language, which defines unpaid internships as placements that support academic learning. Students who participate must be enrolled in journalism programs with an internship component, as the placements are to augment their education. One manager notes, "These are clearly short-term opportunities. We hope that we get some benefit while they're here and perhaps as a young person they have a different life view and they will give us some story ideas, but basically it's to the benefit of students and schools."

\section{Internship Parameters}

The current unpaid intern program in Toronto is set up with five distinct periods per year, to give newsroom producers and shows a fixed schedule to prepare for intern placements and identify available mentors. Colleges and universities handle the initial screening of applicants and are instructed by the CBC to permit only the best students in the class to apply, with a maximum of four students per school for an intern period. While the CBC does not set quotas for gender, race, or ethnicity, schools are made aware that the Corporation wants to ensure diversity in its workforce, and has identified priority communities, including aboriginal and visible minority candidates, and those with disabilities (CBC 2014b). Prospective interns can identify as a member of a priority group in the resume and cover letter accompanying their application.

The decision to offer internships to current college or university students in a journalism program makes internships impossible for those whose financial means or personal situations prevent them from undertaking academic studies. The lack of compensation or funding for travel also puts the possibility of placements in the national newsroom in Toronto or at foreign bureaus out of reach for students who might be outstanding candidates. While the $\mathrm{CBC}$ acknowledges that accessibility may be compromised by the lack of funding, there is no effort underway to address this barrier.

From its inception, the length of unpaid national radio and television news internships was fixed at six weeks. CBC managers argue that this time period is long enough to expose students to the internal workings of the CBC, without creating situations where interns are treated as employees and mistakenly assigned work that contravenes the collective agreement. The union confirms that contract language appears to be adhered to in most situations, with few cases brought to union attention. The CMG observes that the infrequent issues do not originate with senior management, but

where you get a problem is at an operational or department level and it may even be on occasion our own members [...] It can quite often be that they forget this is an intern. Again, I don't think there's any great plan to undermine the contract. [W] hen these things happen, we call somebody, we get back to them, and it gets fixed.

In some cases, interns move through radio, television, and online placements over two-week periods so as to ensure a diverse learning experience.

Successful applicants for an unpaid internship receive a copy of the language in the collective agreement, and the same stipulations are emphasized to CBC staff supervising interns. The union also receives the names and details of individual placements to ensure that interns are not engaged in a way that contravenes the collective agreement. Students must 
be in the graduating year of a program, and either Canadian citizens or landed immigrants, the rationale being that, following their internship, they would be eligible for any offer of paid employment on a casual or contract basis.

CBC staff stress that the agreement does not preclude unpaid interns from taking on meaningful assignments under supervision. One staff member describes feedback from past participants:

They were so excited because they actually got to do real work, because not all of their schoolmates did. They would make coffee or shadow, but they never actually got to do real work, whereas with our [students] that was the whole plan. You don't learn anything by watching; you only learn by doing. It's a lot more work for our people because obviously they had to check everything that the intern did, but in the end the interns got amazing training.

A senior union official stresses that the collective agreement is not a barrier to interns doing work, but that such work "should be under the auspices, or under the direction and guidance, of a mentor." The official also acknowledges the CBC's seriousness, saying, "I think the Corporation has been, as far as I can see, pretty rigid themselves. They try to make sure they enforce this themselves [...] the cases where it's been abused or places where the guidelines or contract [haven't been followed] are few." This is a consistent position among the interviewees in this research-far from being pressed into service to fill staffing shortages, interns are regarded as additions beyond normal levels of staffing, and subject to strict conditions during their placement.

Interns at the CBC work as chase producers, identify possible guests for live news programming and reporter stories, contribute to research on various topics, transcribe audio and video interviews, and gather public reactions to major news stories. Managers and producers had no recollection of any situation in which an unpaid intern in Toronto worked as a reporter during an internship, pointing to both contract language regarding supervision and the unlikelihood that an intern could produce work at a high enough standard for broadcast. In 2014, the Toronto program accepted applications from students at 19 academic institutions. Over a 12-month period, an average of 50 students participate in the national program, which does not include radio current affairs programs or factual entertainment.

The office of the manager of staff development, which is tasked with handling the unpaid internship program in Toronto, does not oversee any program described as an internship in other CBC locations, and does not gather specific data outside of the Toronto program. Other cities, particularly Vancouver and Ottawa, have established histories of student placements in their newsrooms. A number of other $\mathrm{CBC}$ locations have provisions for both unpaid and paid internships of varying duration. In some locations, particularly those near schools with journalism programs, those internships are of long standing, although not overseen by the national office. Others appear to be arranged on an informal basis to accommodate a request by a student fulfilling an internship requirement. There are also unpaid internship programs in CBC bureaus outside Canada, primarily Washington, D.C. and London, England. The London bureau allocates time slots each year to individual schools, which nominate the interns who are considered for the placement. As with domestic internships, students in $\mathrm{CBC}$ internships are responsible for making and paying for their own travel and living arrangements.

Radio-Canada, the CBC's French-language division, also offers unpaid internships. Formal guidelines on Radio-Canada internships were established in 2007 and differ from the model at the Corporation's English language counterpart in several respects. Applicants are not screened by schools and do not have to be studying journalism, though they are required to be in a university program with a requirement for a media course or internship. Students are interviewed by the producers of the shows that are interested in having them as interns, and the timeline is worked out after an internship offer is extended, with greater flexibility possible for the duration. The Radio-Canada program in Montreal accepts about 15 interns per year for editorial placements. 


\section{Academic Institution Participation}

To gauge the response to the CBC intern program, I sent surveys to journalism schools that have taken part in the CBC's intern program. I received responses from 10 English-language academic institutions in five provinces. Every respondent indicates that students receive academic credit for completing an internship, with eight of the 10 schools indicating an internship is a requirement for graduation. Virtually all schools receive either written or verbal communication about the individual student's performance at the conclusion of their students' internships. Five respondents indicate they have occasional contact with the CBC to offer feedback on the program.

The survey asked respondents about the fact that the internships with the national program in Toronto are unpaid, and what percentage of students had concerns about that. Three schools put the percentage at 10 percent or less, with one school putting the percentage at 50 percent. The students' concerns fell into two categories: that all internships should be paid, and the fact the internships were unpaid made it financially impossible to do the internship in Toronto. None of the respondents raised the issue when asked if there are any changes they would like to see in the CBC's intern program. One school explains: "our students expect an unpaid internship in Canada and rarely complain or comment about it being paid. We say it is part of their learning and career research." Only one school, which did not place students in unpaid internships, suggested the CBC should eliminate internships that did not have compensation, saying "unpaid internships are bad news. Get rid of them."

A survey question about how academic institutions regard the unpaid $C B C$ internships brought responses suggesting they were important and valuable. One respondent notes: "students generally get excellent experience at $\mathrm{CBC}$ and we know (anecdotally) that these postings frequently lead to contract positions at $\mathrm{CBC}$ or contract or full-time positions at other news organizations." Another reports "the students always come away feeling confident the skills they learned at the college allowed them to dive in, work and learn." A third school comments that many graduates go on to work at the CBC, and others feel the placement helps to launch their students' careers. A question about any changes schools would like to see brought responses that primarily centre on the length, with some schools suggesting they would be interested in seeing the six-week period extended.

I received written responses from six past interns for this research, who were questioned primarily about their role. One suggests the six-week structure has limitations, saying:

I rotated through the three placements every two weeks. That was hardly enough time to get to know anyone, develop their trust, and barely learn any skills. I struggled to find things to do, to show that I was capable of even writing simple copy [...] It was often very frustrating. I still think I learned a lot from being inside the building, and seeing how the giant CBC machine works-and I did eventually get some copy I wrote on air, or quotes I gathered put into a TV story. But it wasn't nearly as editorially demanding as what I did in school.

Another former intern suggests the opportunities afforded to an unpaid intern are not representative of what an entry-level position as an editorial assistant involves, pointing out that,

as an intern, the students get to learn and do a lot of things, such as chasing, writing, and going out on shoots. But if they somehow manage to get a job after, as I did, EA is the usual starting position [...] and that's a bit disappointing. It can be a long struggle to move up from the EA role!

Another suggests that the chase producer role assigned to some interns limits their interactions, and that there are few opportunities for constructive feedback. The small sample of responses confirms the $\mathrm{CBC}$ and union position that the internships are structured to prevent abuses and use of the interns as unpaid labour filling roles that would otherwise go to paid employees. The responses also suggest while the $\mathrm{CBC}$ and schools report many positive responses to the intern program, some participants do identify limitations with the structure and placements as a learning opportunity. 
The CBC does operate a program that provides graduating students with compensation and work experience, which bears some similarities to the initial summer intern program introduced in 1974. The Joan Donaldson Scholars Program, named for the first head of CBC Newsworld, was established in 1999, which was when the first unpaid interns arrived in the Toronto newsroom. Up to eight graduating students are chosen annually from nine eligible universities, and offered four months of paid work at the entry-level editorial assistant compensation pay level.

While the first summer interns in the 1970s were primarily working as reporters, Donaldson Scholars are less likely to be assigned that way. "They actually let me file four TV reports for the local newsroom, which I was absolutely thrilled about. (I don't think it's something the other Donaldsons got the opportunity to do)," writes one participant in response to questions about the program. A small group of recipients questioned about work assignments suggests that Donaldson Scholars tend to perform production-driven editorial tasks such as going out to the streets to ask people questions on a specific topic, interviewing individuals who would be included in other reporters' stories, working with editors to assemble stories, and working as chase producers identifying potential guests for news shows.

The CBC website refers to the Joan Donaldson Scholars Program as "a paid internship," which recognizes exceptional academic performance and individuals engaged in the world around them, and says the scholarships "provide the CBC with an opportunity to assess high-potential individuals for future employment" (CBC 2015c). One former manager observes of the Donaldson Scholars that "to see them go out the door was not good efficiency, particularly if they worked somewhere else [...] there certainly was an understanding and a desire to keep them." Informal estimates from former managers and participants suggest about half of Donaldson Scholars over the last 15 years are offered some form of employment at the conclusion of the program. While no specific requirements regarding class, gender, race, or ethnicity are identified by the program, 88 of the 126 Donaldson recipients since its inception are women.

\section{The Future of Internships at the CBC}

The CBC plans to reduce its workforce by 25 percent as it approaches 2020 (Wong 2014), but has given no indication it plans to make cuts to the unpaid intern program. While there has been a wider public discussion regarding compensation for internships in the media and elsewhere, there has been no indication that the CBC is considering paying interns who participate in its six-week program. At the current entry-level category of editorial assistant, compensation for fifty interns for six weeks would amount to more than $\$ 190,000$ (CBC-CMG 2014).

While virtually everyone at the $\mathrm{CBC}$ interviewed for this research strongly supports the position that the public broadcaster has a responsibility to provide training and learning opportunities, the CBC is under financial pressure and has been cutting editorial positions. Providing paid internships would also require successful negotiations and support from the CMG. The union has made its commitment to support training for students clear, and provides oversight to ensure the terms of the current collective agreement are met-but any consideration of paid internships would reopen the debate on the impact of short-term employees on staff positions.

While the CBC shows its support for interns by investing time and personnel, financial constraints would appear to rule out devoting further resources to gathering more information about intern outcomes. At no time has the CBC tracked specific employment outcomes at the Corporation for either past Donaldson Scholars or past unpaid interns on a regular basis. One manager points out that while individuals might not be hired immediately, they might become employees a year or two later or work on a short-term contract before leaving for another position, and thus tracking them would be difficult. He explains the Corporation's reasoning on unpaid interns: "If somebody great comes through here we want them for ourselves. If they work at a competitor and it enhances journalism in Canada, we've done our part, we haven't lost." The CBC maintains detailed written records of interview assessments 
from prospective interns and Donaldson Scholars, as well as evaluations from supervisors who oversee interns. These records are used to build a database of individuals who could be offered casual or short-term paid work upon completion of their placement, although interns are told not to expect that outcome.

Only four of the 10 schools that responded to my survey indicate they keep records on whether students obtain paid employment at organizations where they have interned. A survey question about where schools had placed interns at $\mathrm{CBC}$ locations in Canada in addition to Toronto and Montreal over the previous five years resulted in the names of 17 different locations, none of which would have been overseen by the manager of staff development in Toronto. While schools may have records on how many of their students complete internships at the $\mathrm{CBC}$ and at other organizations, that information is maintained internally at the academic institution and no clear national picture exists.

This adds to the case for academic institutions to take a greater role in informationgathering about the outcomes of journalism internships at the CBC and other institutions, and making this information more widely accessible in some form. A national database identifying where interns are placed, the length of placement, and a description of the job responsibilities would contribute to a deepened understanding of the role that $C B C$ internships play in journalism education. With the CBC's stated plan to move to a digital-first strategy that shifts the emphasis away from television and radio offerings and towards mobile coverage, the reality of a smaller workforce at the $\mathrm{CBC}$, and interest from academic institutions for longer internships, reliable data on the number of national placements would be valuable as part of a wider discussion with all of the participating academic institutions about future directions for intern initiatives.

The $C B C$ internship program has been in place for more than 15 years. Formal complaints and legal cases against companies in Canada and internationally has raised a number of concerns about internships, including the absence of legal protections for interns and the possibilities for exploitation by employers intent on availing themselves of unpaid labour (Sagan 2013), and worries that interns' negative comments could affect their future employment prospects (de Peuter, Cohen and Brophy 2012). Investigative series like the one conducted by media organization ProPublica also shine a spotlight on the concerns of post-secondary students unhappy about the reality of paying tuition while working without pay at internships (Hickman 2014).

The CBC's intern program demonstrates that internal structures can be put in place to deal with concerns about workplace exploitation and provide interns with a meaningful experience that offers supervision and mentorship. There is a widespread belief among CBC staff members that, as a public broadcaster, the Corporation has a responsibility to provide training and learning opportunities, and that training interns can benefit all parties, including the union. The CBC-CMG collective agreement provides clear guidelines and a dispute resolution mechanism should a concern be raised by an intern or employee. Above all, the CBC and the union have worked together to ensure that internships are consistently beneficial to the students, and that benefits to the Corporation and the union are the favourable outcome of providing a successful program. In my view, any discussion about whether interns at the CBC should receive monetary compensation opens onto a complicated reality for employers and unions at the $\mathrm{CBC}$ and beyond, namely, how to resolve demands for intern compensation with union concerns that short-term internships at entry-level pay rates would result in reduced positions and job stability for existing employees.

The debate over the pervasiveness and role of internships highlights the need for better information on internships in Canadian journalism to ascertain their use and effectiveness. A clear understanding of what changes might be desirable cannot be advanced without a more comprehensive national picture. Any discussion about making changes to the current internship system in place at the $C B C$ will require the participation of all stakeholders. The $C B C$ and the CMG have a long history of working to respond to the needs of journalism educators. The question now is whether educational institutions are prepared to add to the understanding of the role of internships at the $\mathrm{CBC}$ and beyond by developing a systematic, reliable 
method of gathering information about them. This knowledge could prove crucial in shaping the next chapter in the history of internships at the CBC.

\section{References}

Canadian Media Guild. 1998. Interns. Accessed April 23, 2015. http://www.cmg.ca/en/your-rights-andresources/policies/interns/.

Canadian Media Guild. 2014. About the CBC/Radio-Canada Branch. Accessed November 22, 2014. http://www.cmg.ca/en/cbcradiocanada/about/.

CBC. 2012. CBC Budget Cut by $\$ 115$ million over 3 years. CBC. Accessed February 14, 2015. http://www.cbc.ca/news/politics/cbc-budget-cut-by-115m-over-3-years-1.1147096.

CBC. 2014a. Speaking Notes for Hubert T. Lacroix, President and CEO, CBC/Radio-Canada, at the Canadian Club of Montreal. CBC, Media Centre. May 5. Accessed April 23, 2015. http://www.cbc.radio-canada.ca/en/media-centre/2014/05/5a/.

CBC. 2014b. Our Commitment to Talent and Diversity. CBC. Accessed November 22, 2014. http://www.cbc.radio-canada.ca/en/explore/jobs/talent-diversity/.

CBC. 2015a. Corporate Plan Summary 2014-2015 to 2018-2019. CBC. Accessed April 23, 2015. http://www.cbc.radio-canada.ca/ files/cbcrc/documents/corporate-plan/corporate-plan-summary2014-15-2018-19.pdf.

CBC. 2015b. Compensation Summary. CBC. Accessed February 14, 2015. http://www.cbc.radiocanada.ca/en/reporting-to-canadians/transparency-and-accountability/proactivedisclosure/compensation/.

CBC. 2015c. About the Joan Donaldson CBC News Scholarship. CBC. Accessed April 23, 2015. http://www.cbc.ca/joandonaldsonscholars/about/.

CBC-CMG. 2014. Canadian Broadcasting Corporation-Canadian Media Guild Collective Agreement 2014-19. Accessed November 22, 2014. http://www.cmg.ca/en/wpcontent/uploads/2014/09/CMGCBCCollectiveAgreement20142019.pdf.

de Peuter, Greig, Nicole Cohen and Enda Brophy. 2012. Interns, Unite! You Have Nothing to LoseLiterally. Briarpatch, November 9, 2012.

Government of Canada. 2014 (1991). Broadcasting Act S.C. 1991, c. 11. Accessed April 5, 2015. http://laws-lois.justice.gc.ca/eng/acts/B-9.01/.

Hickman, Blair. 2014. What We Learned Investigating Unpaid Internships. ProPublica, July 23, 2014. Accessed February 14, 2015. http://www.propublica.org/article/what-we-learned-investigatingunpaid-internships.

Mosco, Vincent and Catherine McKercher. 2006. Convergence Bites Back: Labour Struggles in the Canadian Communication Industry. Canadian Journal of Communication 31 (3): 733-751.

Ryerson School of Journalism. 2015. About Us: School History. Accessed November 22, 2014. http://www.ryerson.ca/journalism/about us/history.html.

Sagan, Aleksandra. 2013. Unpaid Intern Hell: Overtime, Tuition Fees. CBC. Accessed April 6, 2015. http://www.cbc.ca/news/canada/unpaid-intern-hell-overtime-tuition-fees-1.1699105.

Wong, Tony. 2014. CBC to Lose up to 1,500 More Jobs. Toronto Star, June 26. Accessed April 23, 2015. http://www.thestar.com/entertainment/television/2014/06/26/strategic plan cuts hubert lacroix.ht $\mathrm{ml}$.

\section{About the Author}

Marlene Murphy

Marlene Murphy is a senior writer at the Canadian Broadcasting Corporation. She has also worked at the CTV Television Network. She has a B.A. (Hons.) from McGill University, and an M.A. in Journalism from Western University. 